\title{
Developing Formative Evaluation Model to Improve Students' Learning Outcome at Vocational High Schools
}

\author{
Atin Prihatin*; Sudiyanto; Hermanu Joebagio
}

Faculty of Educational Technology, Sebelas Maret University, Indonesia

Email: atinprihatin772@gmail.com

\begin{abstract}
Evaluation is divided into several kinds, one of which is formative evaluation. Formative evaluation is appropriately used because the process involves students directly in the learning process and is able to improve students' conceptual understanding. The qualitative data were taken from a field research consisting of: 1) observations, observing the students' activities during teaching-learning process and their learning activities while doing evaluation; 2) Interviews, the techniques used were open interview, the interview conducted with the informants using interview guides and documentation analysis. From the results of the case study, some problems were found. To overcome the problems, a model of formative evaluation needs to be developed in order to provide fast feedback for the students and the teachers. The purpose of this research is to make formative evaluation model for ICT (Information and Communication Technology) learning in Vocational High Schools. The design of the research was research and development of a formative evaluation model. The instruments used were questionnaires for product feasibility tests including book review validation, pre-learning quiz instruments, post-learning quiz instruments and product-segment models. Based on the results of qualitative data, interviews were conducted to both students and ICT teachers, and documentation recorded. It was found that $90 \%$ teachers had not done formative evaluation system well. On one hand, the results of quantitative data analysis show that the results of student learning, especially ICT subjects were still relatively low. From the above data, it can be concluded that it is necessary to do research on the development of formative evaluation model to improve student learning outcomes in Vocational High Schools.
\end{abstract}

Keywords: Formative Evaluation Model; Improving Learning Outcome

\section{Introduction}

Learning is an activity undertaken in creating a conducive learning conditions, so that students are able to interact with the learning environment and obtain certain competencies. A learning process is said to be effective if the implementation of learning is able to support students in improving competence and learning achievement after they follow the learning process. Sani (2013: 46-48) reveals that effective learning activities must meet certain aspects, such as student-centered learning activities, the existence of educational interaction between teachers and students, variations of teaching methods, appropriate and 
useful materials, a conducive environment, and supportive learning tools. He added that the nonfulfillment of these aspects could have an impact on the low student learning outcomes. The low learning outcomes of students will affect their ability in following the next learning program. Learning outcome is one indicator of the success of the learning process, so low student learning outcomes indicate the existence of learning components that have not been managed properly.

In the preliminary study through interviews conducted in SMK Taman Karya Madya Songbanyu Girisubo and SMK N1 Giritontro Wonogiri, it was found that the utilization of various learning resources, methods and instructional media has not been done in schools especially in ICT learning. Many teachers did not explain the learning goals to the students, so they did not know the direction and purpose of learning. Facility, one of which PC computer, was still very limited, so the students could not maximize the use of learning resources. In the process of learning the teachers did not use varied learning methods, so sometimes the students were not interested and just chatted with their friends. The media used by teachers were not complete or only on certain materials. The supporting facility like internet access was also very difficult because of the geographical location of schools that is so far with urban areas. Hence, it is difficult for the students to find additional learning resources and to enrich their insight.

Besides, in the learning evaluation system, the teacher did not involve the students. They only gave the test questions, and the students did the test and collected the results. A few days later, the results were informed to the student in the form of numeric value. From these events, it can be seen that the evaluation conducted by the teacher does not provide feedback or informative feedback to the students. Whereas a good evaluation is an informative evaluation. It means that with the score obtained, the students know their mistakes. If they know their mistakes, then they can improve on the next learning process because one of the characteristics of learning is continuous or sustainable. This is very worrying, because the evaluation of learning is one of the main factors in determining learning outcomes.

Formative evaluation provides feedback to teachers (Arifin., 2009: 20) and students (Fakcharoenphol et al., 2011: 4, Etkina et al., 2006: 1-2) as the basis for improving the learning process and organizing remedial programs for the students. Formative evaluation can be used to communicate individual abilities and student learning processes (McAlpine., 2002: 6). Fakcharoenphol dkk (2011: 4) dan Etkina dkk (2006: 1-2) states that formative evaluation gives students what they need to learn. As a preliminary study, initial research was carried out in class IX TKJ SMK Taman Karya Madya Songbanyu Girisubo consisting of 21 students to find their learning outcomes. The results show that the student's test result has an average of only 68.9. Some get the highest score of $84 ., 0$ and the lowest score is 60.0. When viewed from the aspect of completeness of at least 75 , only about $23 \%$ of students exceeded and $77 \%$ did not pass the test.

The low student learning outcomes can be overcome by providing quick and precise feedback (Cruz., 2011). The solution that can be integrated in learning is to use formative evaluation. Teacher feedback after the error is recognized will help the students aware of their mistakes. Formative evaluation involves students to find ways of assessing their performance on their tasks and providing feedback (Etkina et al., 2006: 22). Feedback in formative evaluation of ICT learning will involve students individually or in groups, so that learning will further enhance students' interest and enthusiasm in learning (Subroto., 2010: 12, Sadler., 1989).

Feedback should be an alternative solution for students who have not understood the concept of learning (Stull., 2011 and Nicol., 2006). Observation of 4 ICT teachers at SMK Taman Karya Madya Songbanyu Girisubo, indicate that 3 teachers did not give feedback from test result to the students. This indicates the role of feedback in the test is underestimated. 
The significance of feedback in ICT learning activities will be realized if ICT teachers have understood the meaning of feedback, feedback function, types of feedback, and who should quickly and appropriately be given feedback during the learning activities (Stul., 2011 and Thoir., 2010). By understanding these concepts, giving the feedback will be right on target. Providing feedback does not even hamper student learning activities but increases the effectiveness and efficiency of ICT learning activities implemented. Based on some previous researches, it is known that formative evaluation can improve student learning outcomes. In addition, Popham (2008: 5) explains that giving feedback in formative evaluation can help teachers and students make changes that will improve student achievement in accordance with lesson plans that have been designed by teachers. Therefore, the researcher conducted a research entitled developing informative evaluation model to improve students' learning outcomes.

\section{Literature Review Learning Outcomes}

According to Suprijono (2009) in Muhammad Thobroni and Arif Mustofa (2011: 22) "learning outcomes are patterns of action, values, understanding, attitudes, appreciation, and skills". In addition, according to Bloom in Muhammad Thobroni and Arif Mustofa (2011: 23) "learning outcomes include cognitive, affective and psychomotoric abilities". According to Lindgren in Muhammad Thobroni and Arif Mustofa (2011: 24), learning outcomes include skill, information, understanding, and attitude. Thus, it can be concluded that the learning outcome is a change in behavior as a whole, not just solely one aspect of human potential. It means that the learning outcomes categorized by educational experts as mentioned above are not seen fragmentarily or separately, but comprehensively.

\section{Formative Evaluation}

According to Bell and Cowie (2002: 8) evaluation or formative evaluation is defined as the process used by teachers and students to recognize and respond to student learning to improve learning. Black and William (1998) in Irons (2008: 23) mentioned that formative evaluation refers to all activities undertaken by teachers and students in self-assessing where there are feedbacks that can shape and develop teaching and learning activities involving teachers and students.

Formative evaluation is very important for students and teachers because this evaluation can be used as a learning material of teachers tailored to the student needs, and with this evaluation, students can change their learning strategies. This evaluation has the potential to make a strong contribution to students, that students are more likely to be open to their strengths and weaknesses and engaged with the conversations with the teachers and/ or their peers. This is because in formative evaluation, there are environments that provide more opportunities to assess themselves and their fellow friends as proposed by Alastair Irons (2008).

From some of the above definitions, it can be concluded that formal formative evaluation is an evaluation conducted by the teachers and the students during learning process. This evaluation is done by providing exercises and quizzes, as well as giving feedback directly to students. Students work on exercises and quizzes at the command of the teacher and get feedback directly. The use of formal formative evaluation is intended to make students get a clear and honest evaluation that can be seen from the student scores and get direct feedback that includes information about the trustworthiness of the answers, exercise discussion, and scores. Teachers use the results of the exercises and quizzes as information on the learning that has been done. 


\section{ICT Learning}

The term ICT (Information and Communication Technology) currently affects human life greatly in various aspects. The higher the ability to utilize ICT is, the higher the ability to compete in life will be. Communication technology that continuously advances will affect the pattern of community communication later (Sudarwan., 2010). According to Tandeur, et.al., (2006): "Information and Communication Technology (ICT) plays an important role in the social, cultural and economic role of computers and internet." Therefore, it can be said that integrating ICT in life, especially in the aspect of education is very important at this time.

In the 21 st century learning, teachers are required to be able to use ICT as a source of learning, one of them is by using internet access. The Internet is an infinite source of information (Slamet., 2009). In addition to being able to use ICT as a learning resource, teachers are also required to be able to create creative and innovative learning integrated with the Profile of ICT Utilization with ICT. According to Suhendar cited by Aloysius (2009), creative and fun learning is very important, because it can help students to succeed in learning, create solutions in solving problems, greatly affect the students' lives, and raise their happiness and satisfaction. The ability of the teachers to integrate ICT into learning will also significantly affect the students' ability to achieve educational goals.

Vocational High School (SMK) is a secondary education that aims to improve the knowledge and skills of the students in order to live independently and follow further education in accordance with vocational programs. Based on the Decree of the Directorate General of Primary and Secondary Management 251/ C /KEP /MN/ 2008 on the spectrum of vocational secondary education expertise, it can be seen that the vocational skill spectrum includes a field of skills and skill competencies.

The use of Computer Technology in the learning activities is greatly felt by students. Therefore, ICT for teachers is the main key in improving the quality of education and relevance so that in the implementation of learning activities, teachers are required to create learning that can attract students and as much as possible take advantage of technological progress momentum, especially by optimizing the utilization of information and communication technology. In this context, ICT can be utilized as a learning medium, professional development of teachers, and the development of learning management systems and learning resources (Brojonegoro., 2006). Scientific adaptation to the development of Information and Computer Technology (ICT) is the demand and the need to create qualified human resources. Therefore, teachers should be able to integrate Information and Computer Technology in learning activities and have more knowledge in applying computer technology learning.

\section{Methodology}

The design of this research is an $\mathrm{RnD}$. The model of formative evaluation development generally consists of 9 out of 10 research and development steps according to Borg Gall (1983: 775) adapted to this development research. Based on the development model, a model of formative evaluation development is developed to improve the learning outcomes of ICT subjects in SMK Taman Karya Madya Songbanyu Girisubo and SMK N 1 Giritontro Wonogiri. Below is an overview of the development model of formative evaluation that will be used. 


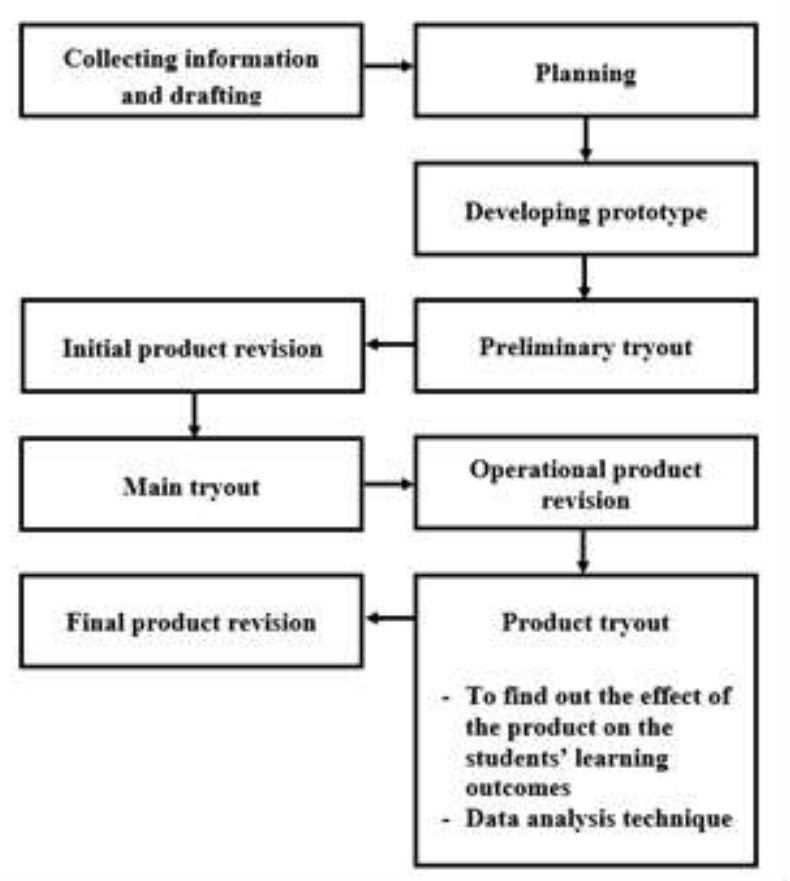

Fig. 1 Design of formative evaluation model development

\section{Drafting}

The objectives of formative evaluation model development are to overcome teachers' difficulties in giving feedback to students, to be used as formative test for the students in the learning process in schools, to make the students understand the concept correctly and independently, to increase selfconfidence and get feedback quickly, to bridge between formative and summative evaluation, and to provide a clear picture to teachers about conceptual understanding through formative evaluation activities.

Formative evaluation model consists of pre-learning, learning, and post-learning stages. In the pre-learning and post-learning stages, the quiz was adapted from the basic and standard competencies in School Based Curriculum (KTSP). The reference materials used in the preparation of a formative evaluation model are ICT books for Vocational and Senior High Schools. In addition, the supporting books in the development of this formative evaluation model are books related to formative and summative evaluation as well as those related to the use in learning. The data and the question items that have been developed are to assist the process of textbook development.

\section{Script Writing}

In this phase, a formative evaluation model and quiz instruments are developed. The manuscript of the formative evaluation model is a textbook that contains an explanation of formative evaluation, development manuals, instruction manuals for teachers, and user manuals for students. The developed quiz instruments consist of pre-learning and post-learning quiz instruments. Pre-learning quiz instrument is in the form of true-false items. Post-learning quiz instrument is in the form of multiple choices. The developed question items aim to understand students' conceptual understanding. Feedback for each item was developed to help students construct their conceptual understanding individually. The quiz instruments refer to SBC. 
After the book script, pre-learning quiz instruments, post-learning quiz instruments, and formative evaluation models had been developed, formative evaluation was undertaken with the evaluation from the expert of formative evaluation and that of ICT materials. After the instruments were revised, a limited tryout to teachers and students was carried out. After second revision, the instruments were tested to the tenth-grade students of Vocational High Schools

The purpose of this product evaluation is to find out whether the feedback developed is in accordance with the aspect of formative evaluation or not. The evaluation was done by a qualified evaluation expert. This evaluation expert has the experience in evaluation for at least 3 years. The product evaluation from the material expert aims to find out how well the questions items are developed and the suitability of the curriculum, with the material on the product that has been made. The selected experts are lecturers of ICT courses with experience of at least 3 years, and ICT teachers who teach ICT at the school. The purpose of this tryout is to find out whether the language used is understandable, the difficulty of operation, and whether the audience is more interested in using the product in learning, and to test the concept understanding after using formative evaluation model. A small group test was conducted on ICT teachers and tenth grade students of Vocational High Schools.

\section{Tryouts}

The technique of collecting data used are non-tests or questionnaires using Likert scale. The evaluation criteria are content, instructional, and technical quality. Quality of content and objectives is about the accuracy, importance, completeness, balance, fairness, and conformity with the student situation. The instructional quality is about providing learning opportunities and assistance for learning, motivating qualities, learning flexibility, test quality and evaluation, and having an impact on students. Technical quality is about legibility, ease to use, display quality, and answer quality.

The developed questionnaire consists of 4 types: book review questionnaire, questionnaire of prelearning quiz instrument, questionnaire of post-learning quiz instrument, and questionnaire of formative evaluation model. Product model of formative evaluation was validated based on the questionnaire.

Evaluation data were taken from evaluation of material experts, evaluation experts, teachers and students. The results of the evaluation were analyzed using percentage technique. The formula used is as follows (Sudjana., 2011: 109).

\section{Population and Sample of Product Tryouts}

The population in this tryout is the tenth-garde students of SMK Taman Karya Madya Songbanyu Girisubo Gunungkidul and SMK N 1 Giritontro Wonogiri. The sample was taken from two classes randomly as experimental and control group. The number of students in 2 classes is 28 students. They were included in the subject of research if they followed all the treatment sequences respectively. ICT learning hours every week is 2 x 40 minutes.

$p=\frac{x}{x_{i}} \times 100 \%$

Notes:

$$
\begin{aligned}
& p: \text { percentage } \\
& x: \text { score of the respondent answer (one item) }
\end{aligned}
$$


$x_{i}$ : ideal score (one item)

The Technique of Data Analysis on Overall Scores

$p=\frac{\sum x}{\sum x_{i}} \times 100 \%$

Notes:

$$
\begin{aligned}
& p: \text { percentage } \\
& \sum x: \text { total score of the respondent answer (one item) } \\
& \sum x_{i}: \text { total of ideal score (one item) }
\end{aligned}
$$

\section{Instruments of Product Tryouts}

The researcher compiled and prepared several test treatment instruments and observation sheets. The treatment test was made in the form of an objective test of multiple choice models with five choices. The test was done after ICT learning activities had finished (3 maeetings). The test was used as a comparison between students who were treated with a formative evaluation model and those who were not. The observation sheet is used to measure the implementation of the learning stages. Both groups got the same learning model. The same learning becomes the control variable.

\section{Data Collection}

There are two types of data collected in this research; they are the scores of tryouts and observation sheet data. The implementers of data collection in the research are ICT teachers in tenth grade of Computer and Networking department who teach at SMK Girisubo Gunungkidul and SMK N 1 Giritontro Wonogiri. The researcher provided an introduction to formative evaluation models and structured test feedback, and explanations of research. As an observer, the researcher was assisted by an observer to observe class activities. The students were given an explanation of the operation of the model. The implementation of this data collection was done for 5 times of learning at the end of semester 2 in tenth grade. One meeting was used to introduce the model and how it operates. Three subsequent meetings were used for data collection and the last was for summative test. The research sequences are described in Figure 2. 


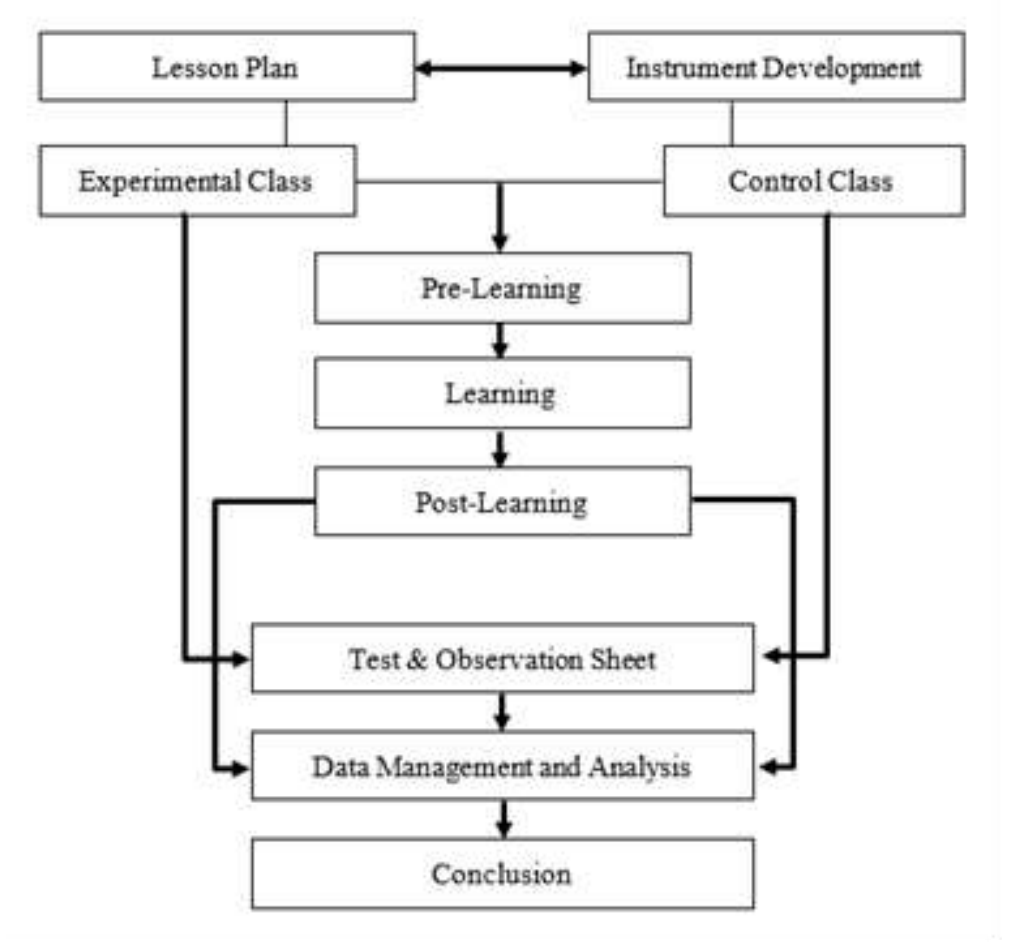

Fig. 2 Suquences of Tryout

\section{Results and Discussions Tryout Data Display}

The presentation of test result data of the formative evaluation model development is grouped into four stages, namely: need analysis, field test, main field test, and product tryout. The needs analysis process includes preliminary study through literature study and field study and drafting product development of formative evaluation model through identification of preliminary study result. The field test process involves the development of a formative evaluation model as the initial product, and the validation by the research-related experts. Major field trial process includes early revision process, and tryouts to teachers and students. The product tryout process includes product operational revisions, product trials and final revisions.

\section{Need Analysis Process}

The observations were conducted by researchers by distributing questionnaires to teachers at schools. The researcher gets the recap to develop a formative evaluation model. The results of the observation show that teachers rarely evaluate before and after learning. The teachers who carry out the evaluation activities at the beginning of learning were only $8.11 \%$ and the teachers who conduct the evaluation at the end of the learning were only $35.14 \%$. In addition, on the multiple-choice test type, teachers prefer to provide feedback only by justifying the choices. From the results of the observations, $97.60 \%$ teachers provided feedback only by giving the correct choice.

Formative evaluation that has been developed previously is formative evaluation model by Otsuka \& Rocha (2007: 36-39). This model is conducted off-line with planning and monitoring phases. In 
addition, there are the model of formative evaluation of the question cycle (Dufresne et al., 2000: 11-14) and Wagner and Vaterlaus formative evaluation models (Wagner \& Vaterlaus., 2011: 2-4) and Margaret Heritage's formative evaluation model. The formative evaluation models can be implemented on-line and offline, and they have been proven to improve student learning outcomes.

Based on the interviews that have been done, it was obtained that the teachers have done formative evaluation in the form of exercises and true-false statements. However, they have not been able to give feedback in a short time. In addition, they have not been able to provide specific feedback to individual students, while students feel more confident when they get feedback personally. The reason for the inability of teachers to provide specific feedback to each student is the limited time allocation of learning and the capacity of the students in one class, making it difficult for teachers to share their attention. Another reason is the length of time the teachers need to make corrections to the students 'work, thereby causing the teachers not to respond quickly to the students' works. Another result is that students prefer formative evaluation applications that provide information about their mastery level and understanding of concepts, point out faults, and discuss missed questions. Time constraints also become an obstacle to formative evaluation at the beginning of the lesson.

Based on these results, the development of a formative evaluation model is needed to assist teachers in conducting formative evaluation, so as to provide specific feedback and improve students' conceptual understanding. The product specification to be developed is based on the initial design of the literature study, and the needs of teacher and students from the field study results. The product specification includes; 1) developing a formative evaluation model; 2) formative evaluation developed in the form of true-false questions for the pre-learning cycle and multiple choice questions for the postlearning cycle; 3 ) providing feedback on the results of the test and explanation of the student's answer error; 4) providing information about the student mistakes adapted from the feedback from each question the student answers; 5) explaining the answer individually; 6) giving the teacher information about the score the students obtain based on the questions answered.

\section{Results of Product Development Design}

The product developed in this research and development is a formative evaluation model developed to assist teachers in conducting formative evaluation in ICT subject so as to improve students' conceptual understanding on the materials. The drafting step of product development began with formulating the basic theory of product development. The next was developing a formative evaluation model. A formative evaluation model was developed based on previous existing formative evaluation models. The next step was to develop indicators of ICT subjects as materials used in product development. The determination of the material ws based on the results of field studies. The researcher made true-false questions for the pre-learning cycle and multiple-choice questions for the post-learning cycle and feedback for each question. Then he constructed the preliminary cycle instructions, postlearning cycle instructions, how-to guides, and teacher and student manuals.

The design of the product development drafting begins with formulating the basic theory of product development. The construction of basic theory serves to facilitate the development of formative evaluation model. The second step was to develop a formative evaluation model. The model was developed based on the previously-developed model. The result of the development process is in the form of formative evaluation model on ICT subject. The product provides pre-learning and post-learning quizes each week. Quizzes can be done more than once in order that the students really understand the theory that has not been or has been learned in the classroom. Each quiz question has feedback that improves students' conceptual understanding. Table 2 presents a description of formative evaluation model in prelearning and post-learning quizzes. 
Table 2 Web-based formative evaluation model

No. Cycles $\quad \begin{gathered}\text { Main cycle } \\ \text { Pre-learning } \\ \text { cycle }\end{gathered}$

\section{Validation}

The developed formative evaluation model was then validated through content validation. Content validation includes booklet validation, generated product development, pre-learning quiz questions and post-learning quiz questions that become components of product development. The validation of product development contents and multiple-choice questions was done by two validators, one lecturer as a material expert, and the other as formative evaluation expert. 


\section{Validation by Validators}

The validation of the contents of the manuscript was done by using questionnaire that has an evaluation scale based on Likert scale. Space was provided in each evaluation indicator item for comments and suggestions. There is a section on the strengths and weaknesses of the manuscript at the end of the questionnaire as well as suggestions for general improvement. The evaluation items used for the manuscript include the material domain, the construction domain, and the language domain.

The data obtained were quantitative and qualitative data. Quantitative data were obtained from Likert scale questionnaire data. Qualitative data were obtained from the strengths and weaknesses and advice on the questionnaire. Quantitative data will be analyzed by percentage method.

\section{Conclusions}

The final product of the development in the research is formative evaluation system to improve student outcomes. The resulting product is used for Vocational High School students who are taking ICT subjects. The product can be developed for use at different levels of students and materials, teachers' developing themselves according to specific material and subjects with similar model systems.

Suggestions that can be put forward are as follows: 1) conducting repetitive product tryouts and encompassing larger numbers of students to better know the quality of pre-learning and post-learning quiz questions, feedbacks, and remedial materials provided by product development, so that the resulting product can be better utilized by teachers and students in the learning process; 2) For the user teachers to ask the students to take pre-learning and post-learning quizzes repeatedly to understand the conceptual errors; 3) The teacher asks the students to read the feedback given.

\section{References}

Arifin, Z. (2009). Evaluasi Pembelajaran. Bandung: PT Remaja Rosdakarya.

Borg, W., R. \& Gall, M., D. (1983). Educational Research. An Introduction (4th ed.). New York: Longman Inc.

Cruz, E. Diaz, H. \& Kortemeyer, G. (2011). The Effect of Formative Assesment in Brazilian University Physics Courses. Revista Brasileira de Ensino de Fisica, 33(4): 4501.

Cohen, A., R. (2005). Measuring the Effect of Formative Assessment Techniques in Physics at East Stroudsburg University. Review of Content Study: the CETP-PA Monograph.

Dufresne, J., Robert, G., J., William. Mestre, P., Jose. \& Leonard, J., William. (2000). ASK.IT /A2L: Assessing Student Knowledge with Instructional Technology. University of Massachusetts Physics Educa-tion Research Group: UMPERG Technical Report PERG-2000\#09-SEP\#1-28.

Etkina, E. (2002). Formative and Summative Assessment in a Physics Class: Time to Change. PERC PUBLISH-ING: 3.

Etkina, E. Heuvelen, V., A. White Brahmia, S. Brookes, T., D. Gentile, M. Murthy, S. Rosengrant, D. \& Warren, A. (2006). Scientific Abilities and Their Assessment. Physics Education Research 2, 020103: 13. 
Fakcharoenphol, W. Potter, E. \& Stelzer, T. (2011). What Students Learn When Studying Physics Practice Exam Problems. Physics Education Research 7, 010107: 4.

Heritage, M. (2009). The Process of Formative Assessment. Presentation at the Meeting of Iowa Assessment for Learning Institute, Des Moines, IA.

Irons, A. (2008). Enhancing Learning Through Formative Assessment and Feedback. Oxon: Routledge.

Margono, G. (2006). Standar Evaluasi Pendidikan. Buletin BNSP: Media Komunikasi dan Dialog Standar Pendidikan, I(2): 40-47.

McAlpine, M. (2002). Principles of Assessment. University of Luton: Computer Assisted Assessment Centre.

Nicol, J., D. \& Dick, D. (2006). Formative Assessment and Self Regulated Learning: A Model and Seven Principles of Goog Feedback Prectice. Published in Studies in Higher Education, 31(2): 199-218.

Otsuka, L., J. \& Rocha, d., V., H. (2007). Online Assessment: Supporting the Formative Assessment of Collaborative Learning Activities. IADIS Intenational Conference: ISBN: 978-972-8924-44-7.

Sadler, R., D. (1989). Formative Assessment and the Design of Instructional Systems. Instructional Science, 18: 119-144.

Stull, C., J. Varnum, J., S. \& Ducette, J. (2011). The Many Faces of Formative Assessment. International Journal of Teaching and Learning in Higher Education, 23(1): 30-39. ISSN 1912-9129.

Sudjana, N. (2011). Evaluasi Hasil Proses Belajar Mengajar. Bandung: PT Remaja Rosdakarya.

Wagner, C. \& Vaterlaus, A. (2011). Promoting Formative Assessment in High School Teaching of Physics. PACS: ISSN 1870-9095.

Wang, X. \& Le, T. (2006). The Discourse of Transition from Summative to Formative Assessment in China. AARE: WAN06117.

Milles \& Huberman. (1992). Analisis Data Kualitatif. Terjemahan Rohendi Rohidi. Jakarta: Universitas Indonesia.

\section{Copyrights}

Copyright for this article is retained by the author(s), with first publication rights granted to the journal.

This is an open-access article distributed under the terms and conditions of the Creative Commons Attribution license (http://creativecommons.org/licenses/by/4.0/). 